\title{
Free Movement as a Means of Subject-Formation: Defending a More Relational Approach to EU Citizenship
}

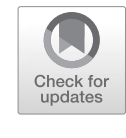

\author{
Päivi Johanna Neuvonen
}

Should EU citizenship 'be primarily about free movement'? According to Floris de Witte, free movement as the core of EU citizenship can contribute to emancipation, justice, and the distinction between the 'nation' and the 'state' within the EU. I share his view that these objectives ought to be important to European integration in general and to EU citizenship in particular. But I am not fully convinced that free movement as 'the central thing that EU citizenship should be about' will automatically result in more just and emancipated relations between EU citizens.

Floris de Witte suggests that free movement as an 'emancipatory force' can make the citizens of the European Union more 'sensitive to the structural process of exclusion that the nation state perpetuates'. For him, free movement can be seen as 'an instrument to problematize these processes'. It nevertheless seems important to consider on what basis free movement would problematize the potentially exclusionary practices within the nation state. Although I am positive about the suggestion that free movement 'orients the individual's visions of self-realisation and self-understanding outwards', I have some reservations about the scope and nature of this emancipatory re-orientation through free movement.

The interesting question is what the term 'outwards' means in the context of EU citizens' free movement. Does the idea of transnational 'selfrealisation' recognise citizenship as an inherently relational form of human interaction and agency, or does it primarily advance an 'atomistic' or 'unencumbered' view of the self? In so far as the normative ideal of free movement is based on the mere objective of individual self-realisation, the danger is that it will foster a narrow and individualistic view of subjectivity for the purposes of European integration. The 'subject' that emerges from the exercise of free movement may easily appear as self-centred, rather than as capable of encountering the 'Other' as part of its own emancipation. ${ }^{1}$

1 For further discussion, see Neuvonen, P.J. (2016), Equal Citizenship and Its

Limits in EU Law: We the Burden. Oxford: Hart.

(C) The Author(s) 2019

R. Bauböck (ed.), Debating European Citizenship, IMISCOE Research

Series, https://doi.org/10.1007/978-3-319-89905-3_22 
According to Floris de Witte, free movement can advance a 'more inclusive way of thinking about what freedom, justice, equality and participation should mean in the EU'. He also writes that free movement as the core of EU citizenship 'benefits all those citizens - whether they make use of it or not'. Here we encounter the question of whether all EU citizens are able to enjoy the right to free movement. I agree with Daniel Thym's point that, if we take seriously the argument that free movement 'ought to be available under similar conditions for all nationals of the Member States', a more comprehensive account of social justice is still needed for the EU. ${ }^{2}$ The idea of free movement may indeed be central to actualising the principles of transnational justice. But it will then be seen as a tool for justice, rather than as an end of EU citizenship.

It seems difficult to justify the non-economic right to free movement and residence without first accepting a more independent equality objective for EU citizenship. Any reference to EU citizenship as an equal status nevertheless raises a set of difficult questions about belonging and solidarity. According to Richard Bellamy, EU citizenship must not bring about the demise of the 'political infrastructure' that advances the degree of solidarity that is arguably required for securing many rights within the Member States. Bellamy's account holds that just relations between citizens can be understood as 'relations of those who share a social space'. But his statist conclusion becomes less self-evident if we assume that 'a social space' can also be constructed transnationally. If equality is understood as a 'normative ideal of human relations', the important question for EU citizenship, as well as for the existence of the EU as an 'emergent polity', is whether it is possible to construct meaningful relations for the purposes of equal treatment outside the context of ex ante belonging.

It seems to me that the argument of self-realisation through free movement does not yet adequately take into account the relational potential of EU citizenship. In his contribution, Floris de Witte refers to 'a 'stateless' or 'anchorless' idea of belonging and community' as the 'strength' of EU citizenship. Although his argument of free movement as an 'emancipatory force' seeks to challenge 'communitarian ties', I hope it would also say more about whether those relationships that constitute a meaningful 'social

2 For further discussion see e.g. Kochenov, D., G. de Búrca \& A. Williams (eds.) (2015), Europe's Justice Deficit. Oxford: Hart.

3 E.g. Scheffler, S. (2007), Equality and Tradition: Questions of Value in Moral and Political Theory. Oxford: OUP, 234.

4 E.g. Wiener, A. \& V. Della Sala (1997), 'Constitution-making and Citizenship Practice - Bridging the Democracy Gap in the EU?' Journal of Common Market Studies 35 (4): 595, 596. 
space' can be transformed and redefined through European integration without just replicating the exclusionary 'community of fate' transnationally? If this question can only be answered in the negative, those authors who are concerned about the harmful implications of EU citizenship for political and social emancipation may have an important point to make. ${ }^{5}$ However, I have argued elsewhere that EU citizens' equal treatment is closely connected to the gradual process of transnational subjectification, the outcome of which may ultimately justify a more positive answer to the above question of meaningful relations. ${ }^{6}$

In sum, free movement can have a central role in constructing a transnational political and legal subject. But I see it as one method of advancing more just and equal relations between EU citizens, rather than as the only objective of EU citizenship. Floris de Witte suggests that 'the added value that EU citizenship can offer primarily lies in its connection to free movement'. However, if the added value of EU citizenship is ultimately connected to how we respond to otherness within the EU, free movement is not the only context in which EU citizens can express their subjectivity as EU citizens in a meaningful way. At the end of his forum post, de Witte, too, seems to come close to this view when he writes that free movement is how the 'virtue' of 'a new - less ethnic - way of thinking about the role of the individual in the EU' is 'implemented'.

Open Access This chapter is licensed under the terms of the Creative Commons Attribution 4.0 International License (http://creativecommons.org/licenses/by/4.0/), which permits use, sharing, adaptation, distribution and reproduction in any medium or format, as long as you give appropriate credit to the original author(s) and the source, provide a link to the Creative Commons license and indicate if changes were made.

The images or other third party material in this chapter are included in the chapter's Creative Commons license, unless indicated otherwise in a credit line to the material. If material is not included in the chapter's Creative Commons license and your intended use is not permitted by statutory regulation or exceeds the permitted use, you will need to obtain permission directly from the copyright holder.

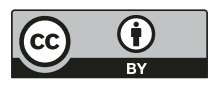

5 E.g. Somek, A. (2014), The Cosmopolitan Constitution. Oxford: OUP, 160-161.

6 Neuvonen, P.J. (2016), Equal Citizenship and Its Limits in EU Law: We the Burden. Oxford: Hart. 